\title{
ANALISIS KUALITAS HASIL GAMBAR SEQUENCE T1 FAT SAT DAN SPECTRAL ADIABATIC INVERSION RECOVERY (SPAIR) PADA POTONGAN SAGITAL MRI PELVIS DENGAN KLINIS ENDOMETRIOSIS
}

\author{
Septi Mawarsari \\ STIKes PERTAMEDIKA, Indonesia
}

\begin{abstract}
Abstrak
Background : Examination of women's pelvis with clinical endometriosis using sequence T1 fat sat with the reason in the description of $\mathrm{T} 1$ fat sat will increase the contrast of the filling, see the difference between tissues containing fat and not, increase the sensitiveness in detecting small endometriosis and help distinguish it from cysts. SPAIR is a very powerful technique for fat suppression, which gives different advantages compared to conventional fat suppression techniques. MRI examination of pelvic endometriosis on sagittal pieces using SPAIR is unlike in theory that more recommend T1 fat sat. Because of the sequence differences, the authors were interested to examine more about the quality of the picture results with the sequence of T1 fat sat and SPAIR on the partal pieces of MRI Pelvic endometriosis.

Method : Design This research is quantitative analytics with observation methods, experiments and questionnaires. Conducted at the MRI Installation of Fatmawati Central General Hospital in February 2016 to May 2016 with a study sample of 10 patients using primary data. T1 Fat Sat and SPAIR overviews are qualitatively analyzed using questionnaires based on the assessment of radiology specialists and radiographers by assessing diagnostic information in terms of anatomy, resolution, contrast and noise. Data analysis is done using Independent $\mathrm{T}$ test.

Result : The result of this study is to show a 'significant difference in anatomy, resolution and contrast characterized by the value $\mathrm{p}$ value $=0.000(\mathrm{p}<0.05)$ while in the noise there is no significant difference marked by $\mathrm{p}$ value $=0.065(\mathrm{p}>0.05)$.
\end{abstract}

Keywords: MRI Pelvic Endometriosis, Image quality, T1 Fat sat, SPAIR

\section{Pendahuluan}

Penyakit Endometriosis adalah penyakit yang $10 \%$ diderita oleh wanita dalam masa premenopause atau wanita di usia reproduktif, dimana ditemukannya jaringan yang menyerupai endometrium di luar uterus yang memicu aksi peradangan kronis. Tahap awal menstruasi (early menarche) dan siklus menstruasi yang pendek berkaitan dengan peningkatan risiko endometriosis (Djuwantono T, 2008). Endometriosis merupakan penyebab umum dari nyeri pada bagian pelvis bahkan menyebabkan kemandulan (Siegelman ES, dkk. 2012). Salah satu keluhan umum para wanita yang menderita gejala endometriosis adalah nyeri pelvik. Gejala-gejala mencakup dismenore, nyeri intermenstruasi, dan dyspareunia. Dismenore merupakan gejala yang paling umum. Dismenore yang berkaitan dengan endometriosis seringkali dimulai sebelum aliran menstruasi muncul dan biasanya bertahan selama menstruasi berlangsung, bahkan terkadang lebih lama dari itu (Leyland N, dkk, 2010). Nyeri biasanya menyebar, berada dalam pelvik, dan dapat menjalar ke punggung, paha, atau berhubungan dengan tekanan usus, kegelisahan, dan diare episodik. Dyspareunia terkait endometriosis biasanya terjadi sebelum menstruasi, lalu terasa semakin nyeri tepat di awal menstruasi. Nyeri ini seringkali berhubungan dengan penyakit yang melibatkan cul-de-sac dan sekat rektovagina.

Terdapat dua jenis endometriosis pada pelvis yang seringkali ditemui adalah endometriosis dalam bentuk difusi, dimana ukurannya sangat kecil dan menyebar, selain itu terdapat endometriosis dalam bentuk focal disebut juga endometrioma atau kista coklat yang mengandung darah (Jensen JR, dkk, 2010). Banyaknya jaringan lemak atau fat pada pelvis membuat pola sinyal yang dihasilkan fat tersebut dalam sequence T1 terlihat sama dan sulit dibedakan dengan pendarahan di endometrium atau dengan pendarahan kista ovarium. Karna hal itulah, teknik fat suppresion dalam MRI pelvis dapat digunakan untuk membatu memperlihatkan perbedaan dari kelainan-kelainan yang ada (Cystic P, 2010). 
Teknik fat supression dapat digunakan untuk lebih menonjolkan kontras antar jaringan dan memperjelas lesi, menentukan suatu jaringan memiliki konten lemak yang tinggi atau rendah serta untuk menghilangkan artefak. Untuk menekan (suppres) sinyal lemak sehingga mengurangi kontribusinya dalam sinyal MRI hal-hal berikut perlu diketahui : lemak dan air memiliki frekuensi resonansi yang berbeda, lemak dan air memiliki frekuensi presesi yang berbeda, mereka memiliki waktu relaksasi T1 yang berbeda (Cameron I, 2009). Teknik saturasi lemak ini tidak bekerja dengan baik pada volume jaringan yang tidak homogen (inhomogeneous).

Penggunaan waktu pada sequence fat sat lebih cepat (Westbrook C, 2014). Fat saturation mempunyai dua keuntungan. Pertama, fat saturation dapat digabungkan dengan tipe sequence imejing lainnya. Kedua , sequence T1 Fat Sat juga dapat digunakan dengan pemeriksaan media kontras gadolinium. Fat saturation sangat sensitif terhadap medan magnet yang homogen. Frekuensi resonansi yang tepat untuk proton lemak tergantung pada medan magnet yang diberikan pada voxel. Jika homogenitas medan magnet tidak sama pada volume gambaran, frekuensi pulsa saturasi akan dihentikan resonansinya untuk beberapa bagian jaringan lemak dan hasil supresinya tidak akan efektif (Brown M a, dkk, 2003).

Spectral Adiabatic Inversion Recovery (SPAIR) adalah teknik yang sangat kuat untuk fat suppression, yang memberikan keunggulankeunggulan berbeda dibanding dengan teknik fat suppression konvensional (Ribeiro MM, 2013).

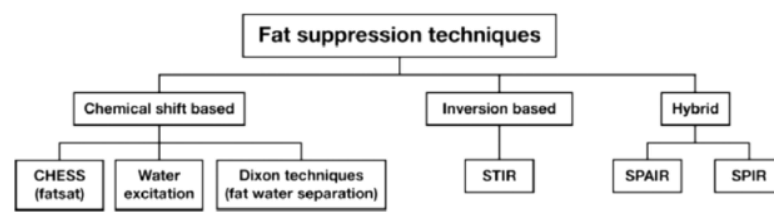

Gambar 1. Tipe-tipe dari teknik fat suppression berbasis chemical shiftberbasis IR dan Hybrid (turunan) (Del Grande F, 2014)

Penggunaan teknik fat suppression SPAIR akan menghasilkan penekanan sinyal lemak yang lebih homogen dibandingkan dengan teknik fat suppression konvensional lainnya. Keunggulan penggunaan SPAIR dibandingkan dengan teknik IR lainnya ditunjukkan dengan terlihatnya peningkatan CNR pada gambaran lesi (Westbrook C, 2013).

\section{Metode}

Desain penelitian yang digunakan adalah kuantitatif analitik berupa studi perbandingan dengan melakukan observasi, eksperimen dan kuisioner. Menurut Soekidjo Notoatmojo Desain Penelitian Kuantitatif adalah Penelitian Ilmiah sistematis terhadap bagian-bagian dan fenomena serta hubungan hubungannya. Penelitian ini diakukan di RSUP Fatmawati pada bulan Februari - Mei 2016 dengan jumlah sampel sebanyak 10 pasien dan pengambilan data primer.

Dalam penelitian ini di gunakan lembar kerja untuk mencatat semua kegiatan yang dilakukan selama penelitian berupa langkahlangkah kerja yang dilakukan dan kuisioner yang diberikan kepada dokter spesialis radiologi dan radiografer berisi pernyataan pilihan untuk mendapatkan data-data tentang kualitas hasil gambaran sagital MRI Pelvis Endometriosis yang memuat informasi anatomi pelvis, resolusi, kontras, dan noise.

Teknik pengambilan sampel purposive yaitu pasien yang melakukan MRI Pelvis dengan klinis Endometrosis. Kriteria inklusi yaitu pemeriksaan MRI Pelvis dengan sequence T1 Fat Sat dan SPAIR, klinis endometriosis dan bersedia menjadi sampel. Kriteria eksklusi yaitu pasien tidak cooperative dan memiliki claustrophobia (takut terhadap ruang sempit atau tertutup) sehingga mengundurkan diri.

\section{Hasil dan Pembahasan}

Setelah dilakukan pengambilan sampel dan penelitian dengan penyebaran kuisioner kepada 7 responden diperoleh data sebagai berikut :

Tabel 1. Rekapitulasi total hasil penilaian 7 responden terhadap 10 hasil gambar T1 Fat Sat dan 10 hasil gambar SPAIR pada gambaran anatomi

\begin{tabular}{ccc}
\hline & T1 Fat Sat & SPAIR \\
\hline Pasien 1 & 2.71 & 3.86 \\
\hline Pasien 2 & 2.43 & 3.43 \\
\hline Pasien 3 & 2.57 & 3.29 \\
\hline Pasien 4 & 3.14 & 3.71 \\
\hline Pasien 5 & 2.86 & 3.43 \\
\hline Pasien 6 & 2.43 & 3.57 \\
\hline Pasien 7 & 2.43 & 3.57 \\
\hline Pasien 8 & 2.86 & 3.43 \\
\hline Pasien 9 & 2.43 & 3.71 \\
\hline Pasien 10 & 2.71 & 3.57 \\
\hline
\end{tabular}


Berdasarkan tabel 1 diatas, diketahui rentang nilai rata-rata anatomi pada T1 Fat Sat yaitu antara $2.43-2.86$, dan rentang nilai ratarata anatomi pada SPAIR yaitu antara $3.29-3$. 86. Dari nilai tersebut diketahui nilai minimal dari hasil penilaian anatomi adalah 2.43 dan nilai maksimal adalah 3.8. Karena banyaknya nilai 2 dari rentang nilai sequence T1 Fat Sat dan nilai 3 pada sequence SPAIR, maka hasil informasi diagnostik dalam menilai anatomi ( uterus, bladder, rectum ) kurang jelas pada T1 Fat Sat dan jelas pada SPAIR.

Tabel 2. Uji normalitas data anatomi hasil gambar T1 Fat Sat dan SPAIR

\begin{tabular}{lccc}
\hline & \multicolumn{3}{c}{ Kolmogorov - Smirnov } \\
\cline { 2 - 4 } & Statistic & Df & Sig. \\
\hline $\begin{array}{l}\text { Rata_rata_Anato } \\
\text { mi }\end{array}$ & .189 & 20 & .060 \\
\hline
\end{tabular}

Pada tabel 2 diatas menjelaskan bahwa hasil uji signifikan rata-rata anatomi hasil gambar T1 Fat Satdan SPAIR memiliki $p$ value $=0.060(p>0.05)$ maka distribusi data normal.

Tabel 3. Independent- Samples T Test nilai anatomi pada hasil gambar T1 Fat Sat dan SPAIR

\begin{tabular}{cccccc} 
& Sequence & $\mathrm{N}$ & Mean & $\begin{array}{c}\text { S. } \\
\text { Deviasi }\end{array}$ & $\begin{array}{c}\text { Sig. } \\
(2- \\
\text { tailed) }\end{array}$ \\
\hline \multirow{2}{*}{ Anatomi } & $\begin{array}{c}\text { T1 Fat } \\
\text { Sat }\end{array}$ & 10 & 2.66 & 0.24 & 0.000 \\
\cline { 2 - 6 } & SPAIR & 10 & 3.56 & 0.17 & 0.000 \\
\hline
\end{tabular}

Pada tabel 3 diatas, besar nilai Sig. (2tailed) menunjukkan nilai keputusan hipotesis, setelah dilakukan analisis menggunakan SPSS versi 21, dengan Independent-Samples T Test didapatkan hasil yaitu adanya perbedaan yang signifikan dari hasil kualitas gambar T1 Fat Sat dan SPAIR pada aspek anatomi, dengan nilai $p_{\text {}}$ value $=0.000(p<0.05)$. Dengan demikian dapat dinyatakan bahwa penggunaan sequence T1 Fat Sat dan sequence SPAIR memiliki perbedaan nilai informasi diagostik dilihat dari rata-rata nilai anatomi hasil gambaran sequence SPAIR lebih besar daripada sequence T1 Fat Sat, sehingga dapat dinyatakan nilai anatomi sequence SPAIR lebih baik dari pada T1 Fat Sat.

Tabel 4. Rekapitulasi hasil penilaian responden terhadap 10 hasil gambar T1 Fat Sat dan 10 hasil gambar SPAIR pada gambaran resolusi

\begin{tabular}{ccc}
\hline & T1 Fat & \multirow{2}{*}{ SPAIR } \\
\hline Pasien 1 & 2.71 & 3.71 \\
\hline Pasien 2 & 2.57 & 3.71 \\
\hline Pasien 3 & 2.00 & 3.29 \\
\hline Pasien 4 & 2.43 & 3.71 \\
\hline Pasien 5 & 2.71 & 3.43 \\
\hline Pasien 6 & 2.57 & 3.57 \\
\hline Pasien 7 & 2.14 & 3.43 \\
\hline Pasien 8 & 2.43 & 3.29 \\
\hline Pasien 9 & 2.57 & 3.71 \\
\hline Pasien 10 & 2.86 & 3.57 \\
\hline
\end{tabular}

Berdasarkan Tabel 4 diatas, diketahui rentang nilai rata-rata resolusi pada T1 Fat Sat yaitu antara $2.00-2.86$, dan rentang nilai ratarata resolusi pada SPAIR yaitu antara 3.29 - 3 . 71. Dari nilai tersebut diketahui nilai minimal dari hasil penilaian resolusi adalah 2.00 dan nilai maksimal adalah 3.71. Karena banyaknya nilai 2 dari rentang nilai sequence T1 Fat Sat dan nilai 3 pada sequence SPAIR, maka hasil informasi diagnostik dalam menilai resolusi kurang jelas pada T1 Fat Sat dan jelas pada SPAIR.

Tabel 5. Uji normalitas data resolusi hasil gambar T1 Fat Sat dan SPAIR

\begin{tabular}{lccc}
\hline & \multicolumn{3}{c}{$\begin{array}{c}\text { Kolmogorov - } \\
\text { Smirnov }^{\mathrm{a}}\end{array}$} \\
\cline { 2 - 4 } & Statistic & Df & Sig. \\
\hline Rata_rata_Resolusi & .180 & 20 & .090 \\
\hline
\end{tabular}

Pada tabel 5 diatas menjelaskan bahwa hasil uji signifikan rata-rata resolusi hasil gambar T1 Fat Sat dan SPAIR memiliki $p$ value $=0.090 \quad(p>0.05)$ maka distribusi data normal.

Tabel 6. Independent- Samples T Test nilai resolusi pada hasil gambar T1 Fat Sat dan SPAIR

\begin{tabular}{cccccc} 
& $\begin{array}{c}\text { Sequenc } \\
\mathrm{e}\end{array}$ & $\mathrm{N}$ & Mean & S. Deviasi & $\begin{array}{c}\text { Sig. (2- } \\
\text { tailed) }\end{array}$ \\
\hline \multirow{2}{*}{ Resolusi } & $\begin{array}{c}\text { T1 Fat } \\
\text { Sat }\end{array}$ & 10 & 2.50 & 0.26 & 0.000 \\
\cline { 2 - 6 } & SPAIR & 10 & 3.54 & 0.17 & 0.000 \\
\hline
\end{tabular}

Pada tabel Tabel 6 diatas, besar nilai Sig. (2-tailed) menunjukkan nilai keputusan hipotesis, setelah dilakukan analisis menggunakan SPSS versi 21, dengan Independent- Samples $T$ Test didapatkan hasil yaitu adanya perbedaan yang signifikan dari hasil kualitas gambar T1 Fat Sat dan SPAIR pada aspek resolusi, dengan nilai $p$ value $=$ $0.000(p<0.05)$. Dengan demikian dapat dinyatakan bahwa penggunaan sequence T1 Fat Sat dan sequence SPAIR memiliki perbedaan 
nilai informasi diagostik dilihat dari rata-rata nilai resolusi hasil gambaran sequence SPAIR lebih besar daripada sequence T1 Fat Sat, sehingga dapat dinyatakan nilai resolusi sequence SPAIR lebih baik dari pada T1 Fat Sat.

Tabel 7. Rekapitulasi hasil penilaian responden terhadap 10 hasil gambar T1 Fat Sat dan 10 hasil gambar SPAIR pada gambaran kontras

\begin{tabular}{ccc} 
& T1 Fat Sat & SPAIR \\
\hline Pasien 1 & 2.43 & 3.86 \\
\hline Pasien 2 & 2.29 & 3.57 \\
\hline Pasien 3 & 2.71 & 3.71 \\
\hline Pasien 4 & 2.43 & 3.57 \\
\hline Pasien 5 & 2.57 & 3.29 \\
\hline Pasien 6 & 2.43 & 3.43 \\
\hline Pasien 7 & 2.57 & 3.57 \\
\hline Pasien 8 & 3.00 & 3.43 \\
\hline Pasien 9 & 2.57 & 3.71 \\
\hline Pasien 10 & 2.86 & 3.71 \\
\hline
\end{tabular}

Berdasarkan Tabel 7 diatas, diketahui rentang nilai rata-rata kontras pada T1 Fat Sat yaitu antara $2.29-3.00$, dan rentang nilai ratarata kontras pada SPAIR yaitu antara $3.29-3$. 86. Dari nilai tersebut diketahui nilai minimal dari hasil penilaian kontras adalah 2.29 dan nilai maksimal adalah 3.86. Karena banyaknya nilai 2 dari rentang nilai sequence T1 Fat Sat dan nilai 3 pada sequence SPAIR, maka hasil informasi diagnostik dalam menilai kontras kurang jelas pada T1 Fat Sat dan jelas pada SPAIR.

Tabel 8. Uji normalitas data kontras hasil gambar T1 Fat Sat dan SPAIR

\begin{tabular}{lccc}
\hline & \multicolumn{3}{c}{ Kolmogorov - Smirnov } \\
\cline { 2 - 4 } & Statistic & Df & Sig. \\
\hline Rata_rata_Kontras & .186 & 20 & .069 \\
\hline
\end{tabular}

Pada Tabel 8 diatas menjelaskan bahwa hasil uji signifikan rata-rata kontras hasil gambar T1 Fat Sat dan SPAIR memiliki $p$ value $=0.069(p>0.05)$ maka distribusi data normal.

Tabel 9. Independent- Samples T Test nilai kontras pada hasil gambar T1 Fat

\begin{tabular}{cccccc}
\multicolumn{6}{c}{ Sat dan SPAIR } \\
\hline Sequence & N & Mean & $\begin{array}{c}\text { S. } \\
\text { Deviasi }\end{array}$ & $\begin{array}{c}\text { Sig. } \\
\left(\begin{array}{c}2 \\
\text { tailed) }\end{array}\right.\end{array}$ \\
\hline \multirow{2}{*}{ Kontras } & $\begin{array}{c}\text { T1 Fat } \\
\text { Sat }\end{array}$ & 10 & 2.59 & 0.22 & 0.000 \\
\cline { 2 - 6 } & SPAIR & 10 & 3.59 & 0.17 & 0.000 \\
\hline
\end{tabular}

Pada tabel Tabel 9 diatas, besar nilai Sig. (2-tailed) menunjukkan nilai keputusan hipotesis, setelah dilakukan analisis menggunakan SPSS versi 21, dengan Independent- Samples $T$ Test didapatkan hasil yaitu adanya perbedaan yang signifikan dari hasil kualitas gambar T1 Fat Sat dan SPAIR pada aspek kontras, dengan nilai $p$ value $=$ $0.000(p<0.05)$.

Dengan demikian dapat dinyatakan bahwa penggunaan sequence T1 Fat Sat dan sequence SPAIR memiliki perbedaan nilai informasi diagostik dilihat dari rata-rata nilai kontras hasil gambaran sequence SPAIR lebih besar daripada sequence T1 Fat Sat, sehingga dapat dinyatakan nilai kontras sequence SPAIR lebih baik dari pada T1 Fat Sat.

Tabel 10. Rekapitulasi hasil penilaian responden terhadap 10 hasil gambar

T1 Fat Sat dan 10 hasil gambar SPAIR pada gambaran noise

\begin{tabular}{ccc} 
& \multicolumn{2}{c}{ gambaran noise } \\
\hline & T1 Fat Sat & SPAIR \\
\hline Pasien 1 & 3.29 & 3.29 \\
\hline Pasien 2 & 3.14 & 3.43 \\
\hline Pasien 3 & 3.43 & 3.14 \\
\hline Pasien 4 & 3.14 & 3.14 \\
\hline Pasien 5 & 3.29 & 3.29 \\
\hline Pasien 6 & 3.29 & 3.57 \\
\hline Pasien 7 & 3.14 & 3.43 \\
\hline Pasien 8 & 3.43 & 3.57 \\
\hline Pasien 9 & 3.00 & 3.29 \\
\hline Pasien 10 & 3.14 & 3.43 \\
\hline
\end{tabular}

Berdasarkan Tabel 10 diatas, diketahui rentang nilai rata-rata noise pada T1 Fat Sat yaitu antara 3.00-3.43, dan rentang nilai ratarata noise pada SPAIR yaitu antara $3.14-3.57$. Dari nilai tersebut diketahui nilai minimal dari hasil penilaian noise adalah 3.00 dan nilai maksimal adalah 3.57. Karena banyaknya nilai 3 dari rentang nilai sequence T1 Fat Sat dan sequence SPAIR, maka hasil informasi diagnostik dalam menilai noise pada kedua sequence baik T1 Fat Sat maupun SPAIR adalah memiliki sedikit noise.

Tabel 11. Uji normalitas data noise hasil gambar T1 Fat Sat dan SPAIR

\begin{tabular}{lccc}
\hline & \multicolumn{3}{c}{$\begin{array}{c}\text { Kolmogorov - } \\
\text { Smirnov }^{\mathrm{a}}\end{array}$} \\
\cline { 2 - 4 } & Statistic & Df & Sig. \\
\hline Rata_rata_Noise & .184 & 20 & .074 \\
\hline
\end{tabular}


Pada Tabel 11 diatas menjelaskan bahwa hasil uji signifikan rata-rata noise hasil gambar T1 Fat Sat dan SPAIR memiliki $p$ value $=0.074$ ( $p>0.05$ ) maka distribusi data normal.

Tabel 12. Independent- Samples T Test nilai noise pada hasil gambar T1 Fat Sat dan SPAIR

\begin{tabular}{cccccc}
\hline \multirow{2}{*}{ Noise } & Sequence & N & Mean & $\begin{array}{c}\text { S. } \\
\text { Deviasi }\end{array}$ & $\begin{array}{c}\text { Sig. } \\
(2- \\
\text { tailed })\end{array}$ \\
\cline { 2 - 6 } & $\begin{array}{c}\text { T1 Fat } \\
\text { Sat }\end{array}$ & 10 & 3.23 & 0.14 & 0.065 \\
\hline
\end{tabular}

Pada tabel Tabel 12 diatas, besar nilai Sig. (2-tailed) menunjukkan nilai keputusan hipotesis, setelah dilakukan analisis menggunakan SPSS versi 21, dengan Independent-Samples $T$ Test didapatkan hasil yaitu, tidak ada perbedaan yang signifikan dari hasil kualitas gambar T1 Fat Sat dan SPAIR pada aspek noise, dengan nilai $p$ value $=0.065$ $(p>0.05)$.

\section{Kesimpulan}

Berdasarkan penelitian yang dilakukan untuk menganalisa kualitas hasil gambaran sequence T1 Fat sat dan SPAIR pada potongan sagital MRI Pelvis didapatkan hasil bahwa terdapat perbedaan yang signifikan dari segi anatomi pelvis, resolusi dan kontras pada hasil gambaran T1 Fat sat dan SPAIR sedangkan dari segi noise tidak memperlihatkan adanya perbedaan yang signifikan, nilai informasi diagnostik dari anatomi, resolusi dan kontras sequence SPAIR lebih tinggi dibandingkan nilai informasi diagnostik pada sequence T1 Fat sat dilihat dari hasil penghitungan rata-rata kualitas hasil gambaran sequence T1 Fat sat dan SPAIR, dan dari hasil analisis menggunakan Independent-Samples $T$ Test pada anatomi pelvis diperoleh $p$ value $=0.000(p<0.05)$, resolusi dengan $p$ value $=0.000(p<0.05)$, kontras dengan $p$ value $=0.000(p<0.05)$, dan noise dengan $p$ value $=0.065(p>0.05)$, sehingga secara garis besar untuk hasil gambaran T1 dengan saturasi pada lemak pada sequence SPAIR lebih baik dibandingkan dengan Fat sat.

\section{Daftar Pustaka}

Brown M a., Semelka RC. MRI Basic Principles and Applications. Third. Canada: John Wiley \& Sons, Inc., Hoboken, New Jersey.; 2003. 1-265 p.

Cameron I. Techniques of Fat Suppression. Ismrm [Internet]. 2009;1-7. Available from: http://cds.ismrm.org/protected/09MProceedings /files/Tues C36_01 Cameron.pdf.

Cystic P, Lesions O. MRI of Benign Female Pelvis. Arrs. 2013;223-30.

Del Grande F, Santini F, Herzka DA, Aro MR, Dean $\mathrm{CW}$, Gold GE, et al. Fat-suppression techniques for 3-T MR imaging of the musculoskeletal system. Radiographics [Internet]. 2014;34(1):217-33. Available from: http://www.ncbi.nlm.nih.gov/pubmed/2442829 2.

Djuwantono T. Diagnosis Endometriosis Dalam Praktik. 2008;

Jensen JR, Coddington CC. Evolving spectrum: the pathogenesis of endometriosis. Clin Obstet Gynecol. 2010;53(2):379-88.

Leyland N, Casper R, Laberge P, Singh SS, Allen L, Arendas K, et al. Endometriosis: Diagnosis and Management. J Obstet Gynaecol Canada. 2010;32(7):S1-3.

Ribeiro MM. STIR, SPIR and SPAIR techniques in magnetic resonance of the breast: A comparative study. J Biomed Sci Eng [Internet]. 2013;6(3):395-402. Available from: http://www.scirp.org/journal/PaperInformation. aspx?PaperID=29562\&\#abstrac

Siegelman ES, Oliver ER. MR Imaging of Endometriosis: Ten Imaging Pearls. Radiographics. 2012;32(6):1675-91.

Westbrook C. Handbook of MRI Technique Fourth Edition. UK: Wiley - Blackwell; 2014. 393 p.

Westbrook C, Roth CK, Talbot J. Mri In Practice 4th Edition. 4TH ed. UK: WILEY BLACKWELL; 2011. 459 p. 